\title{
Development of an Escherichia coli-Lactobacillus casei shuttle vector for heterologous protein expression in Lactobacillus casei
}

\author{
Namfon Suebwongsa ${ }^{1}$, Viraphong Lulitanond ${ }^{1 *}{ }^{*}$, Baltasar Mayo $^{2}$, Panjamaporn Yotpanya ${ }^{1}$
} and Marutpong Panya ${ }^{1,3^{*}}$ (D)

\begin{abstract}
There is an increasing interest to develop various lactic acid bacteria (LAB) species as mucosal delivery vehicles, for which the development of a variety of cloning and expression systems for these bacteria is of primary importance. This study reports the complete nucleotide sequence of the cryptic plasmid pRCEID7.6 derived from the chicken probiotic LAB strain Lactobacillus casei TISTR1341. Sequence analysis and comparison showed that pRCEID7.6 is composed of nine putative open reading frames. The replicon origin of pRCEID7.6 consisted of untranslated origin of replication and translated replication protein B sequences. This region was used to construct Escherichia coli/L. casei shuttle vectors carrying erythromycin and chloramphenicol resistance genes as selective markers. Segregation and structural stability of the vectors in L. casei was sufficient for most genetic applications. The feasibility of this vector for heterologous protein expression in L. casei was determined by cloning in PRCEID-LC7.6, the gene encoding the nucleocapsid protein (NP), from the influenza A virus under the control of the homologous promoter from the lactate dehydrogenase gene. L. casei carrying this recombinant plasmid was shown to successfully express the NP protein. Therefore, this shuttle vector can be used for further study in the development of mucosal delivery vehicles.
\end{abstract}

Keywords: Lactobacillus casei, Plasmid, Cloning vectors, Heterologous expression, Oral live vaccine

\section{Background}

Lactobacillus casei is a member of the lactic acid bacteria (LAB) that can be found in various environments, including that of animal and human intestines (Kandler and Weiss 1986). Besides generally recognized as safe (GRAS) status, many strains of LAB including a number of $L$. casei strains are also recognized as probiotics, defined as "live microorganisms that, when administered in adequate amounts, confer a health benefit on the host" (Hill

\footnotetext{
*Correspondence: viraphng@kku.ac.th; marutpong.p@ubu.ac.th

${ }^{\dagger} \mathrm{V}$. Lulitanond and M. Panya contributed equally to this work.

1 Department of Microbiology and Research and Diagnostic Center

for Emerging Infectious Diseases, Faculty of Medicine, Khon Kaen

University, Khon Kaen 40002, Thailand

${ }^{3}$ College of Medicine and Public Health, Ubon Ratchathani University,

Ubon Ratchathani 34190, Thailand

Full list of author information is available at the end of the article
}

et al. 2014). Some strains of L. casei have been demonstrated to exert probiotic properties, such as anti-infective, anti-tumor, and immunomodulating activity (Kim et al. 2006; Ohashi et al. 1989).

There is now a growing trend in the development of LAB as mucosal vaccines, as well as vehicles for the delivery of therapeutic and prophylactic molecules. A major advantage of using LAB as mucosal delivery vehicles is their ability to be engineered to express both homologous and heterologous proteins. Many studies have successfully used $L$. casei to express a variety of heterologous proteins of viral (Suebwongsa et al. 2013), bacterial (Liu et al. 2014), and mammalian origin (Qiu et al. 2013). One critical step to develop L. casei and other LAB as mucosal delivery vehicles is to construct the expression systems for these bacteria. Generally, most of the genetic

\section{Springer}

(c) 2016 Suebwongsa et al. This article is distributed under the terms of the Creative Commons Attribution 4.0 International License (http://creativecommons.org/licenses/by/4.0/), which permits unrestricted use, distribution, and reproduction in any medium, provided you give appropriate credit to the original author(s) and the source, provide a link to the Creative Commons license, and indicate if changes were made. 
manipulations in the development process are preferred to be done in Escherichia coli than in Lactobacillus species, thus E.coli/Lactobacillus shuttle vectors are the essential part of the process.

The construction of E. coli/Lactobacillus shuttle vectors is usually based on replicons, a DNA region that necessary for plasmid replication, derived from both E. coli and Lactobacillus species. The replicon of later species is derived from cryptic plasmid of Lactobacillus species. For the effective expression system for either homologous or heterologous proteins, the basic biological properties of plasmid vector, for example mode of replication, copy number, and stability, are key factors (Shareck et al. 2004). Previously, the researchers had determined the complete nucleotide sequence from three of the four plasmids derived from $L$. casei TISTR 1341, a probiotic strain isolated from chickens obtained from the Thailand Institute of Scientific and Technological Research (TISTR). The replicons from the largest and the smallest plasmids, pRCEID13.9 and pRCEID2.9 respectively, have already been successfully used to construct $E$. coli/Lactobacillus shuttle vectors (Panya et al. 2012).

In this study, the fourth plasmid of L. casei TISTR 1341, pRCEID7.6, was sequenced and its sequence analyzed. The replicon of this plasmid was then used to generate a new E. coli/Lactobacillus shuttle vector. The vector was successfully used for the expression of NP, a synthetic gene based on the nucleocapsid protein (NP) gene of the influenza A virus, in L. casei. Expression of this protein would allow its use as a mucosal delivery vehicle for oral immunization.

\section{Methods}

Bacterial strains and their growth conditions

Bacterial strains used in this study are listed in Table 1. Lactobacillus strains were cultured statically in de Man Rogosa Sharpe (MRS) medium (Difco, East Molesey, UK) at $37^{\circ} \mathrm{C}$. E. coli cells were grown in Luria-Bertani (LB) broth at $37^{\circ} \mathrm{C}$ with vigorous shaking. When needed, antibiotics were added to the media as follows: for $E$. coli, ampicillin $(100 \mu \mathrm{g} / \mathrm{ml})$, chloramphenicol $(10 \mu \mathrm{g} /$ $\mathrm{ml})$; for $L$. casei, erythromycin $(2.5 \mu \mathrm{g} / \mathrm{ml})$, chloramphenicol $(5 \mu \mathrm{g} / \mathrm{ml})$, and tetracycline $(10 \mu \mathrm{g} / \mathrm{ml})$. White/ blue selection was done on LB agar supplemented with ampicillin, $20 \mathrm{mg} / \mathrm{ml}$ of 5 -bromo-4chloro-3-indolyl- $\beta$ $\mathrm{D}$-galatopyonoside (X-Gal) and $0.4 \mathrm{M}$ of isopropyl- $\beta-\mathrm{D}-$ thiogalactopyranoside (IPTG) (Sigma-Aldrich, St. Louis, MO, USA).

\section{DNA isolation and purification}

Plasmids from $E$. coli were isolated the by an alkaline lysis method, as described by Sambrook and Russell (2001). Plasmids from LAB were isolated by the O'Sullivan and Klaenhammer method (O'Sullivan and Klaenhammer O'Sullivan and Klaenhammer 1993). Total genomic DNA of $L$. casei was extracted and purified from the mid-log

Table 1 List of bacterial strains, plasmids, and oligonucleotide primers utilized in this study

\begin{tabular}{|c|c|c|}
\hline Materials & Relevant properties & Source or reference \\
\hline \multicolumn{3}{|l|}{ Bacteria } \\
\hline Escherichia coli XL-1 Blue & White/blue screening & Stratagene, La Jolla, CA \\
\hline Lactobacillus casei TISTR1341 & Source of pRCEID7.6 native plasmid & TISTR \\
\hline Lactobacillus casei RCEID02 & Plasmid-free L. casei TISTR1341-derivative & Panya et al. (2012) \\
\hline Lactobacillus casei ATCC393 & Plasmid-free stain & ATCC \\
\hline \multicolumn{3}{|l|}{ Plasmids } \\
\hline pUC19E & $A p^{r}, E m^{r}$, pUC19 carrying the $\mathrm{Em}^{r}$ gene from pE194 at the Smal site & Leenhouts et al. (1991) \\
\hline pGEM-T easy & Ap ${ }^{r}$, M13ori, T-overhang cloning vector & Promega, MD, USA \\
\hline pRCEID-LC2.9 & Ap', Emr, E. coli/L. casei shuttle vector based on pRCEID2.9 & Panya et al. (2012) \\
\hline pRCEID-LC13.9TC & $A p^{r}, T C^{r}, p R C E I D-L C 13.9$ derivative, the $T c^{r}$ gene was inserted at Sacl site & Panya et al. (2012) \\
\hline pNZ8048 & $\mathrm{Cm}^{r}, \mathrm{Ncol}$ site used for translational fusions, standard vector & Mierau and Kleerebezem (2005) \\
\hline Oligonucleotides & Sequence $\left(5^{\prime}-3^{\prime}\right)$ & \\
\hline p6.8F-1 & gggtcagttttgccttatg & This study \\
\hline P6.8R-1 & ctggcaatgactttgcgga & This study \\
\hline p6.8F & attgcttggatcctctggcatgacaaac (BamHI) & This study \\
\hline $\mathrm{p} 6.8 \mathrm{R}$ & ctttttggtatacggatccagtcgcta (Kpnl) & This study \\
\hline Spel-Idh_F & caaactagtagcttttagtcctcgtgaaaa (Spel) & Suebwongsa et al. (2013) \\
\hline pnisNdel & attacatatgaagctcgcgttatcggtc (Ndel) & Suebwongsa et al. (2013) \\
\hline
\end{tabular}

Underlined nucleotides show introduced restriction enzyme sites, which are indicated in parenthesis

TISTR Thailand Institute of Scientific and Technological Research, ATCC American Type Culture Collection 
phase of bacterial cultures by using QIAamp DNA Mini Kit according to the instructions of the manufacturer (Qiagen, Hilden, Germany). Purified plasmids were verified by agarose gels electrophoresis, stained with ethidium bromide and visualized under UV light, and photographed.

\section{General DNA manipulation}

General DNA manipulations were performed as described by (Sambrook and Russell 2001). Restriction endonuclease and T4 ligase were obtained from Fermentas (Fermentas, USA), Taq and $P f u$ polymerases were obtained from RBC (RBC, Taiwan). PCR amplicons and DNA fragments from agarose gels were purified using the Gel/PCR DNA Fragments Extraction Kit (RBC, Taiwan) as recommended by the manufacturer. Nucleotide sequences of the recombinant plasmids were verified by sequencing using a MegaBACE 1000 sequencer (BioDesign Co. Ltd., Pathumthani, Thailand).

\section{Plasmid sequencing and assembly}

The contig2310 with a length of $6814 \mathrm{bp}$ had been obtained as reported elsewhere (Panya et al. 2012). This sequence has been found to share high homology to several plasmids from $L A B$ and proved to be unrelated to all other plasmid sequences from $L$. casei TISTR 1341. The researchers assumed the contig could be a major part of a plasmid with the length of $7.6 \mathrm{~kb}$ observed by agarose gel electrophoresis in L. casei TISTR 1341 (Panya et al. 2012). Thus, DNA from the band corresponding to that plasmid was extracted from a gel, purified, and used as a template to amplify the remaining sequence with conventional PCR using the primers $\mathrm{p} 6.8 \mathrm{~F}-1$ and p6.8R-1 (Table 1). The amplicon obtained was cloned into pGEM-T easy vector and sequenced by using the primers $\operatorname{M13F}(-40)$ and $M 13 R(-40)$ (Table 1). The obtained sequence was assembled with that of the previous contig2310 by using CLC Workbench 5.6 program.

\section{Analysis of the plasmid nucleotide sequence}

Nucleotide sequence similarity searches were performed using the BLAST program at the NCBI database (http:// www.ncbi.nlm.nih.gov/BLAST/). Open reading frames (ORFs), Direct (DR) and Inverse (IR) repeat sequences, restriction endonuclease sites, and plasmid maps were determined using Clone Manager 7.0 software. The putative promoter and ribosome binding site (RBS) sequences were searched for by comparing with the consensus sequences (TTGACA for -35 box, TATAAT for -10 box, and AGGAGG for RBS). Protein structure and motives were searched for by using the Pfam search tool (http://pfam.sanger.ac.uk/).

\section{Plasmid transfer}

Plasmids were introduced into either E. coli or L. casei by electroporation. E. coli electroporation was performed using a Gene Pulser apparatus (Bio-Rad, Richmond, CA, USA) as described by Dower et al. (1988). Preparation of competent cells and electroporation of $L$. casei was performed as previously described by (Chassy and Flickinger 1987).

\section{Construction of E. coli/L. casei shuttle vector}

The cloning procedure to obtain the pRCEID7.6-derived shuttle vector is shown in Fig. 2. Initially, a DNA sequence containing the ori, and repB genes from pRCEID7.6 was amplified by PCR using primers $\mathrm{p} 6.8 \mathrm{~F}$ and $\mathrm{p} 6.8 \mathrm{R}$ (Table 1). The amplified segment was cloned into pGEM$\mathrm{T}$ Easy vector resulting in a pGEM:pRCEID7.6Rep. The pRCEID7.6 replicon was recovered from pGEM:pRCEID7.6Rep by double AatII/NdeI digestion and cloned into AatII/NdeI-digested pUC19E, a pUC19 derivative contain $E$. coli replicon that does not replicate in $L$. casei but contains an erythromycin resistance gene as selective marker (Leenhouts et al. 1991), resulting in the construct pRCEID-LC7.6. To change the selective marker from erythromycin-resistant gene $\left(\mathrm{Em}^{\mathrm{R}}\right)$ to chloramphenicol-resistant gene (cat), the pRCEID-LC7.6 was digested with SalI to remove the $\mathrm{Em}^{\mathrm{R}}$ gene and was self-ligated, giving rise to pRCEID-LC7.6ery-. The chloramphenicol resistant gene (cat) was obtained from pNZ8048 by double SalI/SpeI digestion and was inserted into SalI/SpeI-digested pRCEID-LC7.6ery-, resulted in pRCEID-LC7.6Cm.

\section{Segregational and structural stability of the constructs}

The segregational and structural stability of a pRCEIDLC7.6 shuttle vector was studied in L. casei RCEID02, a plasmid-free derivative from $L$. casei TISTR 1341. Transformants with pRCEID-LC7.6 were grown in MRS broth without erythromycin for approximately 200 generations. Every 20 generations, an aliquot of the culture was removed, diluted, and plated onto antibiotic-free MRS medium. One hundred colonies were selected and then replicated on MRS agar with and without erythromycin. For segregational stability, colonies grown on MRS agar with and without antibiotics were counted and calculated as follow: $\left(\mathrm{N}_{\mathrm{A}}\right.$ / $\mathrm{N}_{\mathrm{NA}}$ ) $\times 100$, where $\mathrm{N}_{\mathrm{A}}$ and $\mathrm{N}_{\mathrm{NA}}$ is number of colonies appearing on MRS plate with and without erythromycin, respectively. For plasmid structural stability was checked by restriction analysis of plasmids isolated from colonies grown on MRS agar supplement with erythromycin at approximately 20, 40, 60, 80 and 100 generation intervals. 


\section{Determination of plasmid copy number}

Real-time quantitative PCR was used to determine the relative copy number of pRCEID-LC7.6 in L. casei RCEID02 as described by (Lee et al. 2006). The copy number of the constructs was calculated using the formula $\mathrm{N}_{\text {relative }}=(1+E)^{-\Delta \mathrm{CT}}$, where $E$ is amplification efficiency of the target $\left(\mathrm{Em}^{\mathrm{R}}\right)$ and reference (greA) genes, and $-\Delta \mathrm{CT}$ is the difference between the threshold cycle number of the reference gene and that of the target. DNA amplification and detection was performed in a Fast Real-Time PCR equipment (Applied Biosystems, Foster City, CA, USA) using SYBR ${ }^{\circledR}$ Green (Power SYBR ${ }^{\circledR}$ Green PCR Master Mix, Applied Biosystems).

\section{Compatibility of the construct}

The compatibility of pRCEID-LC7.6Cm with other vectors was assayed in L. casei RCEID02. Competent cells of L. casei harboring pRCEID-LC7.Cm were electrotransformed with pRCEID-LC2.9 and pRCEID-LC13.9Tc. Transformants were grown on MRS agar supplemented with appropriate antibiotics. The colonies on MRS agar were randomly selected for plasmid isolation. The plasmid profile was verified by agarose gel electrophoresis.

\section{Construction of pRCEID-LC7.6:LdhL:NP:TT}

The DNA segment containing the promoter of the lactate dehydrogenase (LdhL) gene, the synthetic gene encoding the NP protein of influenza $A$ virus and a transcription terminator (TT) obtained from pNZ8048, was amplified from pLC13.9:LdhL:NP:TT (Suebwongsa et al. 2013) using primers SpeI-ldh_F and pnisNdeI (Table 1). The amplicon was digested with SpeI/NdeI and inserted into pRCEID-LC7.6 digested with the same restriction endonuclease enzymes, resulting in pRCEID-LC7.6:LdhL:NP:TT.

\section{Detection of NP by Western blotting analysis}

The bacterial cell lysates obtained by sonication from overnight cultures of E. coli and L. casei RCEID02 transformants containing pRCEID-LC7.6:LdhL:NP:TT were subjected to SDS-PAGE (12\% of SDS-PAGE, $100 \mathrm{~V}$ for $2 \mathrm{~h}$ ) and their proteins transferred from the gel to a nitrocellulose membrane (Bio-Rad, Hercules, California, USA) by using the Trans-Blot ${ }^{\circledR}$ SD Semi-Dry Electrophoretic Transfer Cell (Bio-Rad, Hercules, California, USA). The NP protein on the membrane was detected by a chemiluminescent detection system (CL-XPosure Film; Thermo Scientific, West Palm Beach, Florida, USA) using antiAvian Influenza A Nucleoprotein antibody (Abcam, Cambrideg, UK), HRP-conjugated anti-rabbit IgG antibody (Abcam, Cambrideg, UK), and SuperSignal West Pico Chemiluminescent Substrate (Thermo Scientific, West Palm Beach, Florida, USA).

\section{Nucleotide sequence accession number}

The complete nucleotide sequence of pRCEID7.6 was deposited in the GenBank database under accession number JN793951.

\section{Results}

Sequencing, sequence comparison and assemblage of pRCEID7.6

Initially, the contig2310 with a total length of 6814 bases showed a nucleotide identity of 96 and $87 \%$ of the segments embraced by the positions 696-3639 and 5944-6814 respectively to sequences of plasmid pCD01 (AY662330.1) from Lactobacillus paracasei NFBC338, strongly suggesting that the contig may be part of pRCEID7.6, the missing plasmid of $L$. case $i$ TISTR 1341 (Panya et al. 2012). To verify this possibility and to complete the nucleotide plasmid sequence, primers in opposite orientation were designed based on the sequence flanking both sides of the contig and used in PCR amplifications using as a template plasmid pRCEID7.6 isolated from a gel. A single amplicon of $1 \mathrm{~kb}$ was obtained which was subsequently cloned in E. coli in the pGEM-T vector and double stranded sequenced. Finally, assemblage of the new sequence to that of contig2310 produced a total 7604 bp which, after analysis, was considered to constitute the whole molecule of pRCEID 7.6.

\section{Sequence analysis of pRCEID7.6}

The genetic organization of the plasmid pRCEID7.6 is depicted in Fig. 1. Nucleotide and deduced amino acid comparisons against the GenBank database predicted that pRCEID7.6 was composed of nine ORFs larger than 50 amino acids. The products of these ORFs and the most homologous protein in databases to each of them are listed in Table 2.

The product of three ORFs, $\operatorname{repB}$, ORF3, and ORF7, encoded putative proteins involved in plasmid replication. The rep $B$ gene encoded a protein of 259 amino acids with $100 \%$ amino acid identity with the replication protein B (RepB) of plasmid pCD01 (YP_003329273.1) from L. paracasei. Upstream of the repB gene of pRCEID7.6, a putative origin of replication (ori) region was observed, including a DR of 10-bp (ATACTTCTAA) repeated two times, and a tandem DR of 22-bp (ATAGGTCACCAAAAAGCACACG) repeated four times followed by a truncated repeat (ATAGGTCACCAAAAAG). This organization resembles the typical feature of the thetareplicating plasmid family of pUCL287 (Kanatani et al. 1995). Downstream of the 22-bp DR, a putative promoter (TTGtgtn15TtaAAT) was found. In addition, a possible ribosome binding site (RBS) (GAGGTG) downstream of the promoter was observed $7 \mathrm{bp}$ upstream from the start codon of repB (ATG). Therefore, based on sequence 


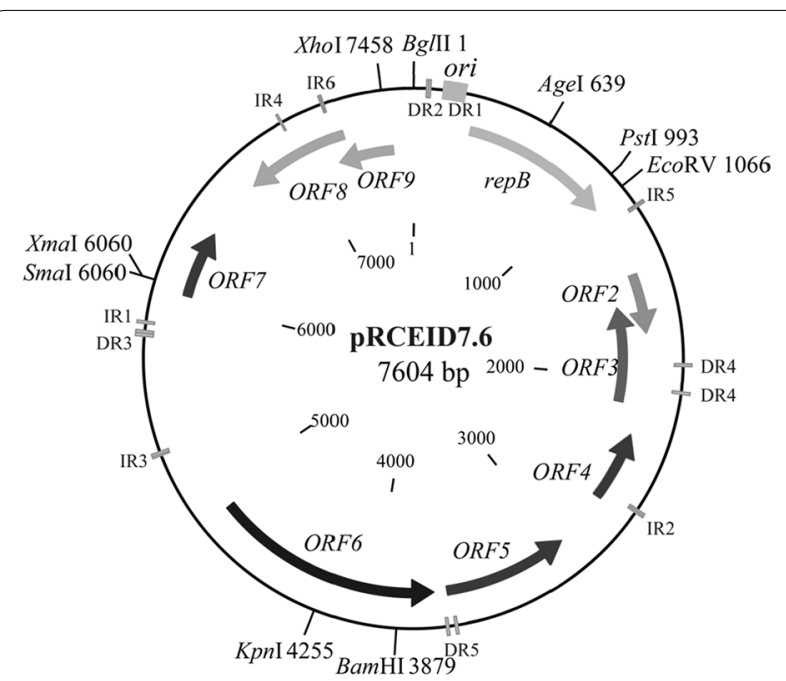

Fig. 1 Physical and genetic map of the plasmid pRCEID7.6 (7604 bp) from L. casei TISTR1341. Arrows indicate the length and direction of the ORFs. Relevant unique restriction enzyme sites are indicated. The ori region of the plasmid is denoted by a solid box. DR direct repeats, IR inverted repeats

similarity, pRCEID7.6 could be reasonably ascribed to the theta-mode of replication.

Surprisingly, the gene product of ORF3 and ORF7 also showed homology to replication-associated proteins. ORF3 encoded 179 amino acid that have a $100 \%$ identity to whole replication protein of plasmid pCD01 (YP_003329275.1) from L. paracasei NFBC338. Similarly, the gene product of ORF7, a protein of 116 amino acids, showed $99 \%$ (115 amino acid identity) sequence identity to a 116 amino acids of putative replication protein of plasmid pLR001 (YP_002221586.1) from L. paracasei HN001. However, since the immediate upstream sequence of these two ORFs lack the typical features of ori region, such as those described for $\operatorname{rep} B$, they are considered to be non-functional for the replication of pRCEID7.6

ORF2 and ORF4 encoded protein with unknown function. ORF2 encoded 103 amino acid with $97 \%$ similarity to hypothetical protein of plasmid pCD01p08 (YP_003329274.1) from L. paracasei. ORF4 encoded a protein of 122 amino acids with $100 \%$ similarity to an hypothetical protein of plasmid1 (YP_796451.1) from $L$. casei ATCC334. A conserved RBS (GGGAGA) was found at 7 bp upstream of the start codon (ATG) of ORF4. The gene product of ORF5 consisted of 216 amino acids with $100 \%$ homology to an hypothetical protein of plasmid1 of L. casei ATCC334 (YP_796451). ORF8 and ORF9 were found to encode proteins responsible, most likely, for plasmid recombination and integration. ORF8 encoded a protein of 178 amino acid s with $96 \%$ identity to transposases (ZP_04672204.1) from L. paracasei 8700:2. This protein is known as a member of transposase family with DDE_Tnp domain (PF01609). Similarly, ORF9 encoded a protein of 106 amino acids with $100 \%$ identity to transposase (tnp4) (CAQ65752.1) from L. casei BL23 and transposase AEA57601.1 from L. casei BD-II.

ORF6 encoded a peptide very similar to the partial part of C-terminal domain of a type IC specificity subunit protein with Methylase_S domain (pfam, PF01420). This domain is also known as a member of target recognition domain (TRD) involved in bacterial restriction-modification system.

\section{Construction and characterization of the E. coli/L. casei shuttle vectors}

Figure 2 shows the cloning steps for constructing the pRCEID7.6-derived E. coli/L. casei shuttle vectors. From the sequence analysis, it was considered that the pRCEID7.6 replication region (including the ori sequence and $\operatorname{rep} B$ ) could consist in the DNA segment encompassing the nucleotide positions from 135 to 1076. Primers were designed to amplify this region and the resulting amplicon was cloned in E. coli in pUC19E. As this vector carries an erythromycin resistance gene active in Grampositives, the construct pRCEIC-LC7.6 was then electrotransformed into L. casei RCEID02 where it proved to drive plasmid replication.

For the vector to be compatible with the two previous vectors developed from other plasmids from the $L$. case $i$ TISTR 1341 strain, the erythromycin resistance gene of construct pRCEID-LC7.6 was changed by a chloramphenicol resistance gene, giving rise to plasmid pRCEIDLC7.6Cm (Fig. 2). It was found that pRCEID-LC7.6 could compatibly replicate with both pRCEID-LC2.9 and pRCEID-LC13.9Tc in the same bacterial host (Fig. 3).

Structural and segregational analysis in $L$. casei RCEID02 indicated that the vector pRCEID-LC7.6 was maintained in 75 and $16 \%$ of the cells after 100 and 200 generations, respectively, in the absence of selective pressure (without antibiotics) (Fig. 4). Additionally, structural changes of plasmid after 100 generations were never observed (Fig. 5). The relative copy number per chromosome equivalent of the constructs was found to be 12 copies per chromosome in L. casei RCEID02.

\section{Expression of a heterologous protein in L. casei RCEID02 using pRCEID-LC7.6}

To determine whether pRCEID-LC 7.6 can be used for expression of heterologous proteins, the construct pRCEID-LC7.6:LdhL:NP:TT was developed. It is a pRCEID-LC7.6 derivative carrying an expression cassette composed of the $l d h$ gene promoter, a codonoptimized, synthetic gene encoding the NP of influence 
Table 2 Open reading frames (ORFs) identified in the 7604-bp plasmid pRCEID7.6 from L. casei TISTR1341

\begin{tabular}{|c|c|c|c|c|c|c|c|}
\hline Gene/ORF & $\%$ GC content & $5^{\prime}$ end position & $3^{\prime}$ end position & No. of aa. & $\begin{array}{l}\text { Known protein with the } \\
\text { highest homology } \\
\text { (microorganism) }\end{array}$ & $\begin{array}{l}\% \text { amino } \\
\text { acid identity } \\
\text { (length) }\end{array}$ & $\begin{array}{l}\text { GenBank } \\
\text { accession no. }\end{array}$ \\
\hline \multirow[t]{2}{*}{$\operatorname{rep} B$} & \multirow[t]{2}{*}{39} & \multirow[t]{2}{*}{297} & \multirow[t]{2}{*}{1076} & \multirow[t]{2}{*}{259} & $\begin{array}{l}\text { Plasmid replication } \\
\text { protein, RepB }\end{array}$ & \multirow[t]{2}{*}{$100(259)$} & \multirow[t]{2}{*}{ YP_003329273.1 } \\
\hline & & & & & $\begin{array}{l}\text { Plasmid pCD01 p07 } \\
\text { (L. paracasei subsp. } \\
\text { paracasei) }\end{array}$ & & \\
\hline ORF2 & 42 & 1461 & 1772 & 103 & $\begin{array}{l}\text { Hypothetical protein of } \\
\text { plasmid pCD01p08 } \\
\text { (L.paracasei subsp. } \\
\text { paracasei) }\end{array}$ & $97(100)$ & YP_003329274.1 \\
\hline $\mathrm{ORF}^{\mathrm{a}}$ & 41 & 1609 & 2148 & 179 & $\begin{array}{l}\text { Putative replication } \\
\text { protein of plasmid } \\
\text { pCD01 (L. paracasei } \\
\text { subsp. paracasei) }\end{array}$ & $100(179)$ & YP_003329275.1 \\
\hline $\mathrm{ORF}^{\mathrm{a}}$ & 36 & 2316 & 2684 & 122 & $\begin{array}{l}\text { Hypothetical protein } \\
\text { LSEI_A19 of plasmid1 } \\
\text { (L. casei ATCC334) }\end{array}$ & $100(122)$ & YP_796451.1 \\
\hline $\mathrm{ORF5}^{\mathrm{a}}$ & 39 & 2977 & 3627 & 216 & $\begin{array}{l}\text { Hypothetical protein of } \\
\text { plasmid1 (L. casei) }\end{array}$ & $100(216)$ & YP_005351865 \\
\hline $\mathrm{ORF}^{\mathrm{a}}$ & 38 & 3696 & 4886 & 396 & $\begin{array}{l}\text { C-terminus part of type } \\
\text { IC specificity subunit } \\
\text { protein (L.rhamnosus) }\end{array}$ & $92(180)$ & ZP_04439481.1 \\
\hline ORF7 & 43 & 6027 & 6377 & 116 & $\begin{array}{l}\text { Plasmid replication } \\
\text { protein of pLR001 } \\
\text { (L. rhamnosus HNO01) }\end{array}$ & $99(115)$ & YP_002221586.1 \\
\hline ORF8 & 45 & 6701 & 7237 & 178 & $\begin{array}{l}\text { Transposase (L. paracasei } \\
\text { subsp. paracasei 8700:2) }\end{array}$ & $96(165)$ & ZP_04672204.1 \\
\hline \multirow[t]{3}{*}{ ORF9a $^{a}$} & \multirow[t]{3}{*}{45} & \multirow[t]{3}{*}{7168} & \multirow[t]{3}{*}{7488} & \multirow[t]{3}{*}{106} & $\begin{array}{l}\text { Transposase tnp4 } \\
\text { (L. casei BL23) }\end{array}$ & $100(106)$ & YP_002221607.1 \\
\hline & & & & & $\begin{array}{l}\text { Transposase } \\
\quad \text { (L. rhamnosus HN001) }\end{array}$ & $100(106)$ & YP_002221607.1 \\
\hline & & & & & $\begin{array}{l}\text { Transposase } \\
\quad(\text { L. buchneri ATCC 11577) }\end{array}$ & $100(106)$ & ZP_03943910.1 \\
\hline
\end{tabular}

a ORFs are encoded on the complementary strand

A virus, and a transcription terminator derived by PCR from pLC13.9:LdhL:NP:TT (Suebwongsa et al. 2013) was introduced into $E$. coli XL-1 blue and $L$. casei RCEID02. Expression of the NP protein in both hosts was determined by Western blot analysis. As shown in the Fig. 6, a protein of the expected size of NP (56 kD), and identical to that of a cell lysate infected with the influenza virus H1N1 used as a control, was clearly revealed in transformants of the two species. In addition, the expression level of NP in L. casei RCEID02 after using the different plasmids, pRCEID-LC 7.6 and pRCEID-LC13.9 as backbone vector, was compared. It was found that that expression level of NP in L. casei RCEID02 was not difference as shown in Fig. 7.

\section{Discussion}

Lactobacillus casei is a member of LAB that has drawn a lot of attention as the candidate for the development of mucosal delivery vehicles (Wen et al. 2012). This bacterial species has been recognized as safe and certain strains possess probiotic properties conferring various health benefits to the hosts (Dong et al. 2013). For example, L. casei strain Shirota was demonstrated to enhance NK cell activity by dairy intake (Takeda and Okumura 2007; Takeda et al. 2006). It has been demonstrated that oral administration of $L$. casei Shirota in humans can prevent and reduce the risk of the occurrence of bladder carcinoma (Aso et al. 1995; Ohashi et al. 2002). Besides probiotic properties, $L$. casei has the most essential property for development as a mucosal delivery vehicle, the ability to be genetically engineered. For genetic engineering in L. casei and other LAB, plasmid replicons are generally required to develop the genetic tools for manipulation. The researchers' previous study (Panya et al. 2012) sequenced and analyzed three cryptic plasmids present in L. casei TISTR1341 


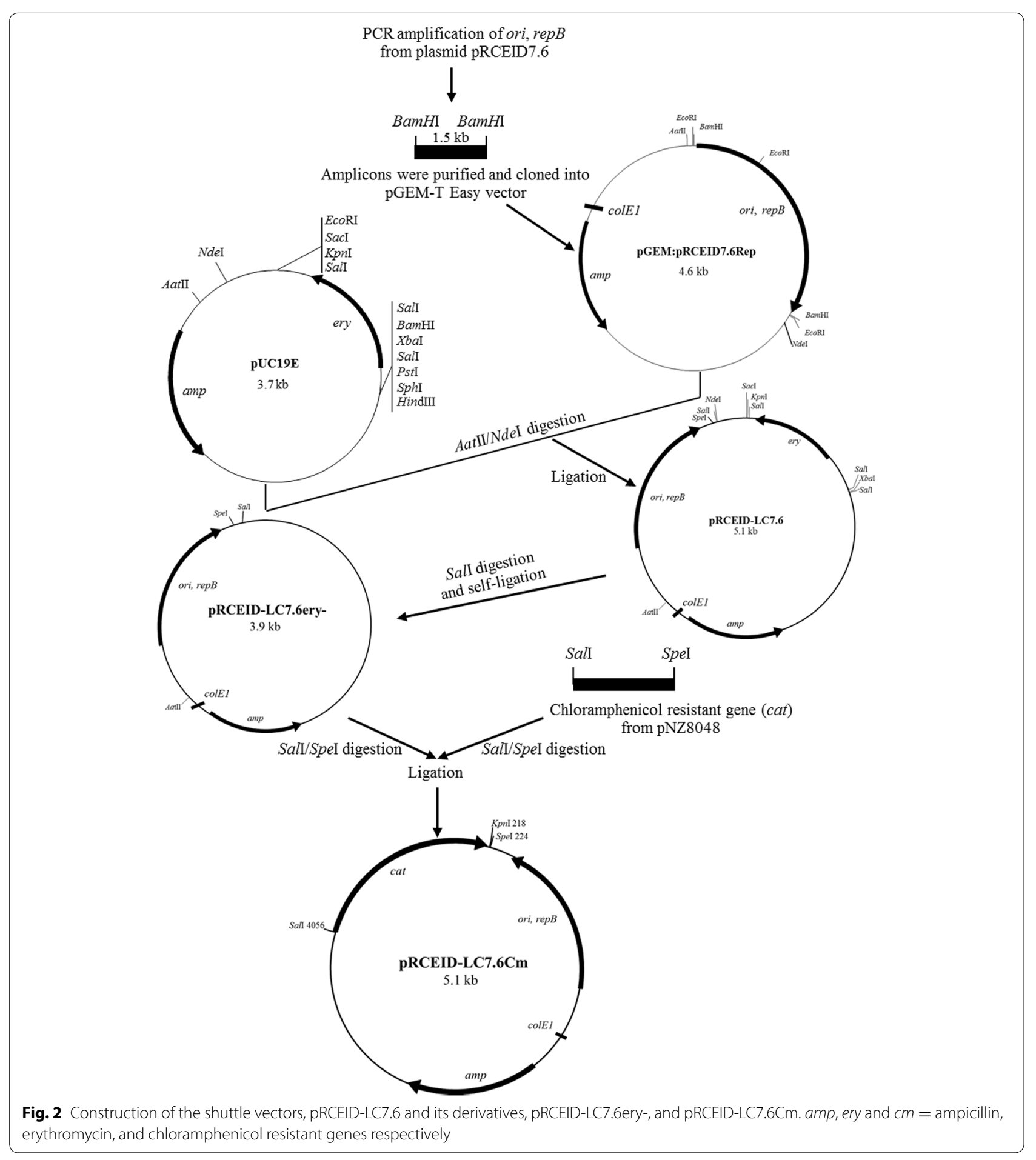

and selected two replicons, one from pRCEID13.9 and the other from pRCEID2.9, to construct E.coli/Lactobacillus shuttle vectors, pRCEID-LC13.9 and pRCEIDLC2.9 respectively. Due to the high structural and segregational stability of pRCEID-LC13.9, this vector was successfully used for expressing the nucleocapsid protein of influenza A virus in L. casei RCEID02 (the plasmid-free derivative of $L$. casei TISTR1341) in the researchers' subsequent study (Suebwongsa et al. 2013). In this present work, the pRCEID7.6 were completely sequenced and analyzed. The replicon of pRCEID7.6 was identified and selected to construct a new shuttle 


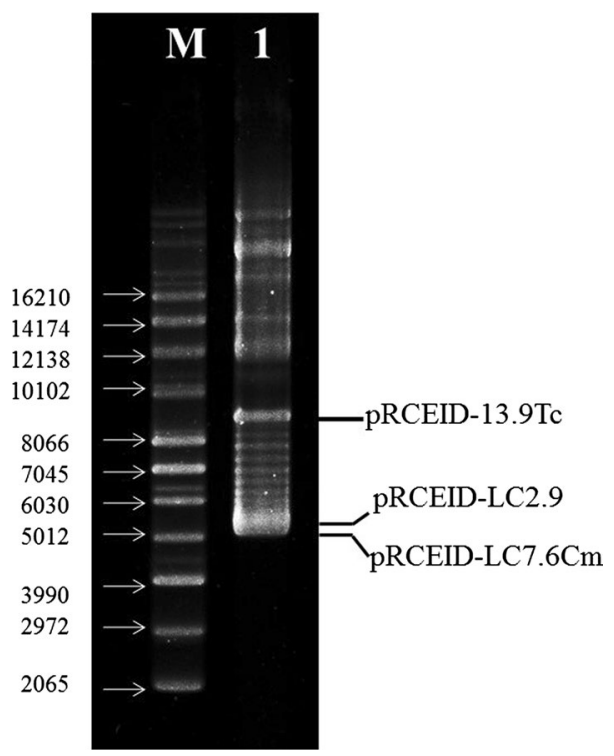

Fig. 3 Ethidium bromide staining agarose gel of plasmid profile of L. casei RCEID02 harboring pRCEID-LC7.6Cm (5.1 kb), pRCEIDLC2.9 (5.3 kb), and pRCEID-LC13.9TC (7.1 kb). Lane 1 plasmid profile of $L$. casei RCEID02 harboring pRCEID-LC7.6Cm, pRCEID-LC2.9, and pRCEID-LC13.9Tc. Lane M Super coiled DNA ladder (Invitrogen, USA). On the left, sizes in base pairs of the different molecules of the ladder. The electrophoresis reaction was carried out by using $0.7 \%$ agarose gel electrophoresis in $\times 1$ TAE buffer at 50 voltages for $3 \mathrm{~h}$

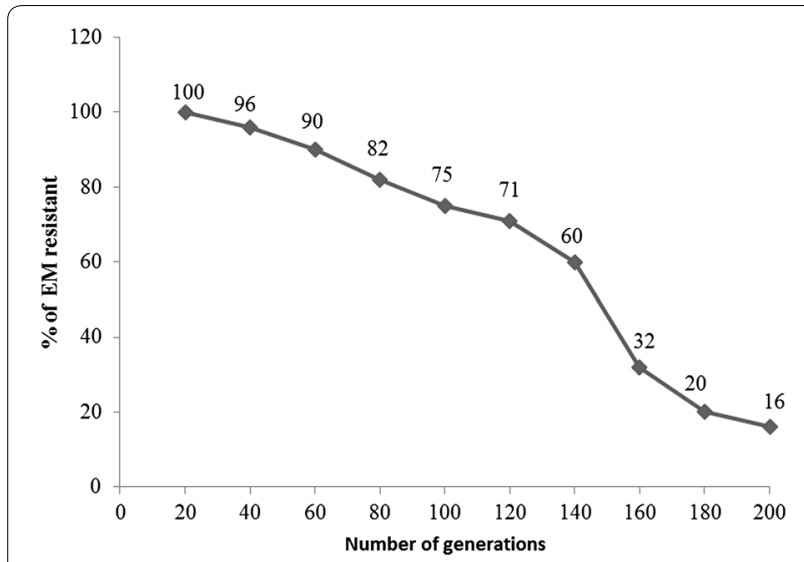

Fig. 4 Segregational stability of the shuttle vectors pRCEID-LC7.6 in $L$. casei RCEID02. L. casei RCEID02 harboring these plasmids was culture in the absence of selective pressure, plated on the same condition, and assayed for plasmid maintenance by replica-plating onto erythromycin-containing MRS medium at approximately 20,40, 60, 80, 100, 120, 140, 160, 180 and 200 generation intervals. Em erythromycin

vector using pUC19E as backbone. The new vector, pRCEID-LC7.6, showed excellent structural stability as there was no structural change after 100 generations. For segregation stability, though the stability was

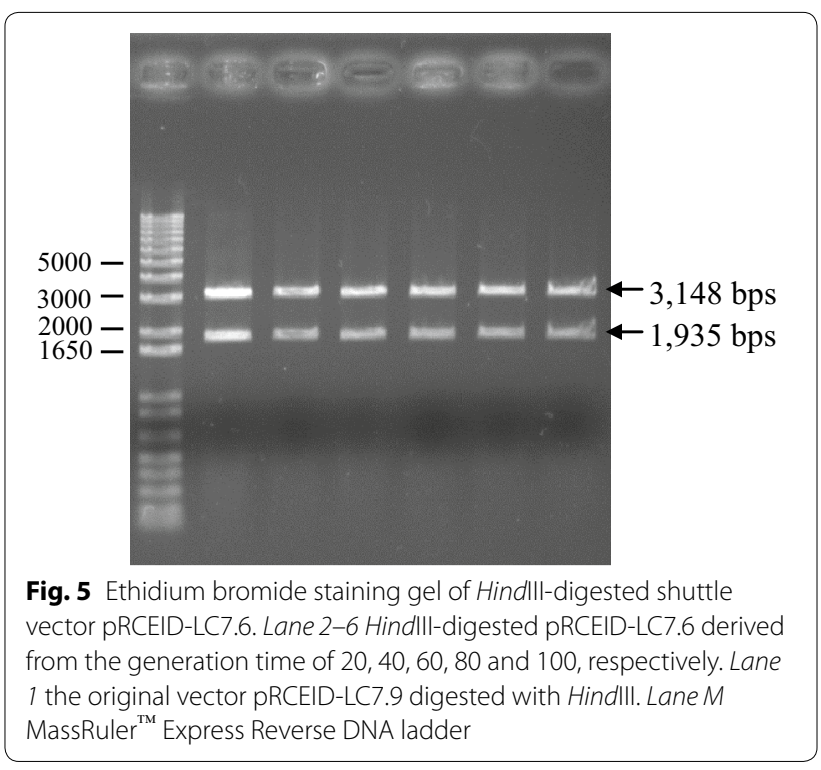

less than that of pRCEID13.9 and pRCEID-LC2.9, and it was sufficient (75 and $16 \%$ after 100 and 200 generations, respectively) for protein expression and other genetic processes in this system. Though not thoroughly verified, replication in other strain of $L$. casei is expected as pRCEID-LC13.9 and 2.9 were shown to be able to replicate in different $L$. casei strains (Panya et al. 2012). In addition, as this vector can replicate with both pRCEID13.9 and pRCEID2.9 in a single cell, this allows the development of more robust, naturally compatible vectors. Finally, pRCEID-LC7.6 was used for the expression of NP of influenza A virus under the control of lactate dehydrogenase promoter in L. casei RCEID02. The successful expression of a heterologous protein in L. casei in this study allows further promising development of this vector as a mucosal delivery vehicle in the near future.

\section{Conclusion}

The present study reported the completion of the plasmid complement of L. casei TISTR 1341, which consists in four plasmids, pCREID2.9, pRCEID3.2, pCREID7.6, and pRCEID13.9. As the replicons of all four plasmids are naturally compatible, the development vectors based on these plasmid replicons would provide high flexibility for cloning and expression of homologous and heterologous proteins in $L$. casei and other LAB species. The suitability of the new cloning vector pRCEID-LC7.6 was demonstrated by cloning and expressing the nucleocapsid protein-encoding gene from the influenza A virus. Expression of this protein would allow its use as a mucosal delivery vehicle for oral immunization. 


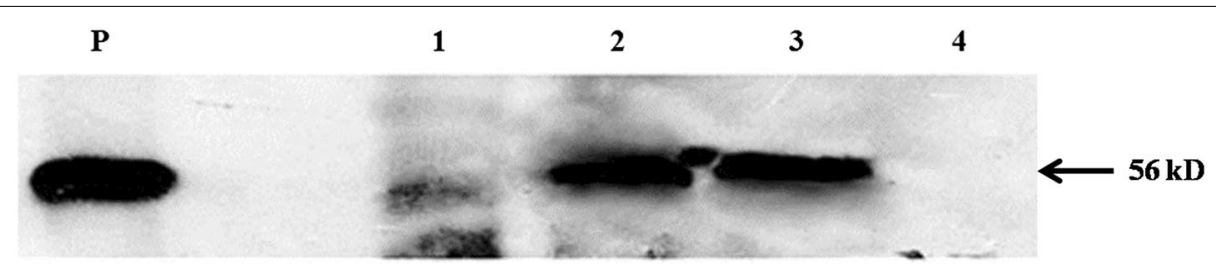

Fig. 6 Western blot analysis of expressed NP in recombinant L. casei RCEID02 and E. coli XL-1 blue containing NP gene using goat anti-NP polyclonal antibody for detection. Lane P Influenza virus H1N1 infected cell lysate. Lane 1 E. coli XL-1 blue containing pRCEID-LC7.6. Lane 2 recombinant E. coli XL-1 blue containing pRCEID-LC7.6:LdhL:NP:TT. Lane 3 recombinant L. csei RCEID02 containing pRCEID-7.6:LdhL:NP:TT. Lane 4 L. casei RCEID02 containing pRCEID-LC7.6

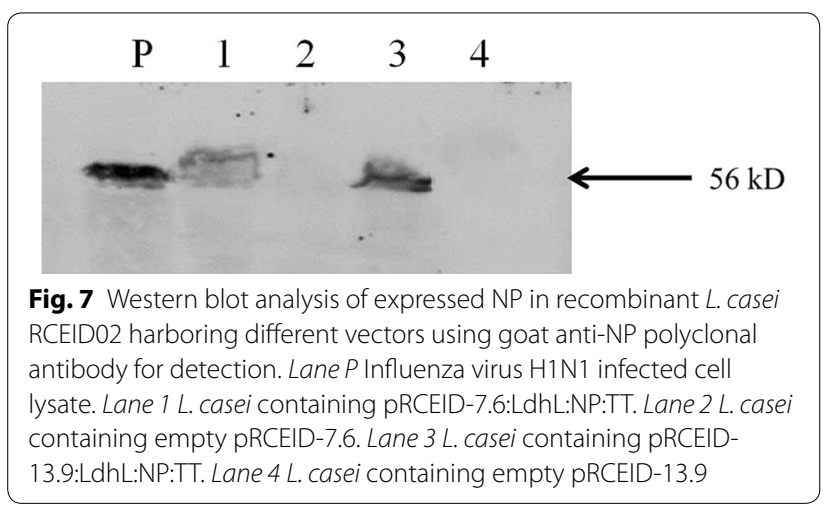

\section{Authors' contributions}

NS, PY and MP designed the research plan and performed the experiments. $\mathrm{BM}$ and MP analyzed and interpreted the data. VL and BM have done the proofreading of the manuscript. VL and MP have been involved in drafting and revision of the manuscript. All authors read and approved the final manuscript.

\section{Author details}

${ }_{1}^{1}$ Department of Microbiology and Research and Diagnostic Center for Emerging Infectious Diseases, Faculty of Medicine, Khon Kaen University, Khon Kaen 40002, Thailand. ${ }^{2}$ Departamento de Microbiología y Bioquímica, Instituto de Productos Lácteos de Asturias (IPLA-CSIC), Paseo Río Linares, s/n, 33300 Villaviciosa, Asturias, Spain. ${ }^{3}$ College of Medicine and Public Health, Ubon Ratchathani University, Ubon Ratchathani 34190, Thailand.

\section{Acknowledgements}

This study was supported by a Higher Education Research Promotion, National Research University Project of Thailand. Thanks are expressed to the staff of the Office of International Relations at Ubon Ratchathani University for assistance with English.

\section{Competing interests}

The authors declare that they have no competing interests.

Received: 13 July 2015 Accepted: 12 February 2016

Published online: 24 February 2016

\section{References}

Aso Y, Akaza H, Kotake T, Tsukamoto T, Imai K, Naito S (1995) Preventive effect of a Lactobacillus casei preparation on the recurrence of superficial bladder cancer in a double-blind trial. The BLP Study Group. Eur Urol 27:104-109
Chassy BM, Flickinger JL (1987) Transformation of Lactobacillus casei by electroporation. FEMS Microbiol Lett 44:173-177

Dong H, Rowland I, Thomas LV, Yaqoob P (2013) Immunomodulatory effects of a probiotic drink containing Lactobacillus casei Shirota in healthy older volunteers. Eur J Nutr 52:1853-1863

Dower WJ, Miller JF, Ragsdale CW (1988) High efficiency transformation of E. coli by high voltage electroporation. Nucleic Acids Res 16:6127-6145

Hill C, Guarner F, Reid G, Gibson GR, Merenstein DJ et al (2014) Expert consensus document. The International Scientific Association for Probiotics and Prebiotics consensus statement on the scope and appropriate use of the term probiotic. Nat Rev Gastroenterol Hepatol 11:506-514

Kanatani K, Tahara T, Oshimura M, Sano K, Umezawa C (1995) Cloning and nucleotide sequence of the gene for acidocin 8912, a bacteriocin from Lactobacillus acidophilus TK8912. Lett Appl Microbiol 21:384-386

Kandler O, Weiss N (1986) Genus Lactobacillus. In: Sneath PHA, Mair NSM, Sharpe ME, Holt JG (eds) Bergey's manual of systematic bacteriology, 9th edn. Williams and Wilkins, Baltimore, pp 1063-1065

Kim YG, Ohta T, Takahashi T, Kushiro A, Nomoto K, Yokokura T et al (2006) Probiotic Lactobacillus casei activates innate immunity via NF-kappaB and p38 MAP kinase signaling pathways. Microbes Infect 8:994-1005

Lee CL, Ow DS, Oh SK (2006) Quantitative real-time polymerase chain reaction for determination of plasmid copy number in bacteria. J Microbiol Methods 65:258-267

Leenhouts KJ, Tolner B, Bron S, Kok J, Venema G, Seegers JF (1991) Nucleotide sequence and characterization of the broad-host-range lactococcal plasmid pWVO1. Plasmid 26:55-66

Liu JK, Wei CH, Hou XL, Yu LY (2014) Passive protection of mice pups through oral or intranasal immunization of dams with recombinant Lactobacillus casei vaccine against ETEC F41. Res Vet Sci 96(2):283-287

Mierau I, Kleerebezem M (2005) 10 years of the nisin-controlled gene expression system (NICE) in Lactococcus lactis. Appl Microbiol Biotechnol 68:705-717

Ohashi T, Minamishima Y, Yokokura T, Mutai M (1989) Induction of resistance in mice against murine cytomegalovirus by cellular components of Lactobacillus casei. Biotherapy 1:89-95

Ohashi Y, Nakai S, Tsukamoto T, Masumori N, Akaza H et al (2002) Habitual intake of lactic acid bacteria and risk reduction of bladder cancer. Urol Int 68:273-280

O'Sullivan DJ, Klaenhammer TR (1993) Rapid mini-prep isolation of high-quality plasmid DNA from Lactococcus and Lactobacillus spp. Appl Environ Microbiol 59:2730-2733

Panya M, Lulitanond V, Tangphatsornruang S, Namwat W, Wannasutta R, Suebwongsa $\mathrm{N}$ et al (2012) Sequencing and analysis of three plasmids from Lactobacillus casei TISTR1341 and development of plasmid-derived Escherichia coli-L. casei shuttle vectors. Appl Microbiol Biotechnol 93:261-272

Qiu ZB, Chen J, Chen JJ, Rong L, Ding WQ, Yang HJ et al (2013) Effect of recombinant Lactobacillus casei expressing interleukin-10 in dextran sulfate sodium-induced colitis mice. J Dig Dis 14:76-83

Sambrook J, Russell DW (2001) Molecular cloning: a laboratory manual, 3rd edn. Cold Spring Harbor Laboratory Press, Cold Spring Harbor 
Shareck J, Choi Y, Lee B, Miguez CB (2004) Cloning vectors based on cryptic plasmids isolated from lactic acid bacteria: their characteristics and potential applications in biotechnology. Crit Rev Biotechnol 24:155-208 Suebwongsa N, Panya M, Namwat W, Sookprasert S, Redruello B, Mayo B et al (2013) Cloning and expression of a codon-optimized gene encoding the influenza A virus nucleocapsid protein in Lactobacillus casei. Int Microbiol 16:93-101

Takeda K, Okumura K (2007) Effects of a fermented milk drink containing Lactobacillus casei strain Shirota on the human NK-cell activity. J Nutr 137:791-793
Takeda K, Suzuki T, Shimada SI, Shida K, Nanno M, Okumura K (2006) Interleukin-12 is involved in the enhancement of human natural killer cell activity by Lactobacillus casei Shirota. Clin Exp Immunol 146:109-115

Wen LJ, Hou XL, Wang GH, Yu LY, Wei XM, Liu JK et al (2012) Immunization with recombinant Lactobacillus casei strains producing K99, K88 fimbrial protein protects mice against enterotoxigenic Escherichia coli. Vaccine 30:3339-3349

\section{Submit your manuscript to a SpringerOpen ${ }^{\odot}$ journal and benefit from:}

- Convenient online submission

- Rigorous peer review

- Immediate publication on acceptance

- Open access: articles freely available online

- High visibility within the field

- Retaining the copyright to your article

Submit your next manuscript at $\gg$ springeropen.com 